Alalakh) in 1937 among the multitude of settlement mounds in its area, or the divining, season after season, at Ur of the most significant quarter to unearth in the great city. There he conducted, beginning from 1926, his most famous operation, revealing the royal tombs of Sumerian rulers who had held sway over the city in a period of unequalled splendour, about 2,500 B.C. as now believed, unhappily just before wxiting, already in use, had learned to record history.

In this great discovery also was best exercised the next in order of Woolley's talents, namely, a fine appreciation of materials in the ground, how they should each be reached, traced, or penetrated, how objects sighted should be protected from impacts of tools or of the atmosphere, how they should be lifted, and how first-aid should be given for their protection, transport, and even their ultimate reconditioning. Many almost deceptively 'well-preserved' exhibits in museums are now substantially as they left Woolley's hands, not restored or falsified, but skilfully extricated by him and remoulded to the shapes which they had lost by decay and pressure of earth. Much of his work of this kind was brilliantly improvised in days which, although not long past, were before the very recent development of preservation laboratories and techniques in museums.

Woolley had, moreover, a notable facility of exposition, which worked in two ways: an attractive lecturer and writer for general audiences, he was also -more important for one whose discoveries could well speak for themselves-a judicious author of excavation reports, that difficult marginal literature which, always bulky, is worthless if it strives for effect, repulsive and unreadable if too painfully 'scientific'. Woolley's many publications were highly successful in these two kinds ; his popular works are both interesting and well founded upon his discoveries (whereas his few attempts at more general themes are not very valuable), and his large volumes of excavation reports have the virtues of well-arranged matter, ample pictures and plans, and careful description based upon his industrious recording in the field. Such deseriptive parts can nearly always be read with interest and ready understanding. Some have, indeed, criticized his observation as not being of the exactitude demanded by the most recent methods, and it is true that Woolley could be intuitive in his perception of archæological levels and his mental reconstructions of buildings and fragments. But such criticisms seem not to make enough allowance for the character of most Near Eastern sites, and the pell-mell of dwellings and artefacts of different ages, often jumbled to gether, which they usually exhibit.

Woolley's lively mind and exploring intelligence, if they sometimes led him beyond his evidence, were of more service in suggesting many true and fruitful consequences of his discoveries. These, as great and varied as have fallen to any modern digger, are his principal bequest and his enduring memorial.

$$
\text { C. J. GADD }
$$

\section{Dr. Eric Boehm}

Dr. Eric Boenm, who died suddenly at Cardiff on December 28, was a well-known and respected figure in industrial chemical and pharmaceutical circles. Born in Breslau, Silesia, sixty-one years ago, he served a pharmaceutical apprenticeship in the town of Schreiberhau and later studied at. the University of Berlin, graduating in 1922. He followed this with postgraduate training which, in 1925, resulted in the award of a Ph.D. He later studied bacteriology at the Robert Koch Institute in Berlin. The pre-war political situation in Berlin forced him and his family to leave Germany for Great Britain.

As a research worker he had become associated with Prof. Sabaletschka after the latter had introduced the now well-known esters of $p$-hydroxy-benzoic acid. Their association resulted in establishing these compounds under the trade names of 'Nipa Esters' as extremely useful, reliable and non-toxic preservatives for pharmaceutical and medicinal products and for foodstuffs. In 1938 these two workers showed that esters of gallic acid showed very promising antioxidant activities; this led to the widespread use of propyl gallate as an anti-oxidant for animal fats to prevent or retard rancidity. Its proved non-toxicity was recognized in 1948 when the United States officially approved its incorporation in fats for human consumption, to be followed by similar recognition in Britain and elsewhere.

In 1942, Boehm showed that certain mono-aryl and mono-alkyl ethers of ethylene glycol possess bactericidal activity. Interest centred chiefly around the phenyl ether of ethylene glycol ('Phenoxetol'), which was investigated bacteriologically and clinically by Berry, Gough et al. It showed unusual activity against Ps. pyocyanea and during the War, in the early days of penicillin, when topical application to wounds was, of necessity, used, a combination of 'Phenoxetol' with penicillin widened the antibacterial spectrum of the latter and also prevented its decomposition in the wound.

Dr. Boehm was that rare combination of an able scientist and capable business administrator. $\mathrm{He}$ also combined rare intellectual qualities with integrity, charm and kindness, as those who had the privilege of knowing him can testify.

H. BERRY

\section{Prof. H. Stansfield}

Prof. Herbert Stansfield, whose death occurred on March 14, was appointed to the chair of physics and electrical engineering at University College, Southampton, in 1912. Previously he was a lecturer in physics in the Victoria University, Manchester. In 1919 he was transferred, with other Departments of the College, from the old Hartley Building to the new site at Highfield.

Research undertaken at Southampton by various members of his staff, under his direction, was started in the late 'twenties. His main interest was in optics, particularly with modifications to the Michelson interferometer experiments on the velocity of light. One summer he co-operated with the Royal Navy on sound recordings of gunfire. Setting up his apparatus in an area where no reports were expected, many yards of photographic paper recordings from an Eindhoven string galvanometer were processed and examined, and the nil report confirmed.

Past students will remember Prof. Stansfield's very characteristic action in stroking his fountain pen on his beard in order to charge some piece of electrostatic equipment in lecture demonstrations. Another characteristic was his exceptionally dry skin. He would touch $200-\mathrm{V}$. terminals with his fingers and then to be quite sure he would moisten them and repeat the action and remark, "Yes, I am sure they are alive"! 
He retired in 1932 at the age of sixty, and the opportunity was then taken to separate the Department of Electrical Engineering at Southampton from Physies, and join it with the Departments of Civil and also Mechanical Engineering in the Engineering Faculty.

$$
\text { C. E. Chester }
$$

\section{Mr. W. H. Searle, B.E.M.}

William Searle, who was for sixty-three years fisherman collector on the staff of the Marine Biological Association of the United Kingdom, died at Plymouth on April 6, at the age of eighty-four. 'Bill', as he was affectionately known by all, must live in the memory of a great number of biologists, from all over the world, who visited the Plymouth laboratory either as research workers or students. It can be truly said that he played a very important part in the development of marine biology through his remarkable knowledge of the fauna and flora and its local distribution as far afield as Salcombe. $\mathrm{He}$ was able to produce almost any organism when required, though their specific names were not easy to interpret when marked by a broad Devonshire accent. Searle joined the Association's staff in December 1895, and worked tirelessly and devotedly, for many years single-handed, in small vessels which have become part of the history of marine biology, Anton Dohrn, Busy Bee, Huxley, Oithona and finally Gammarus, now in her thirty-seventh year.

He was elected an associate member of the Marine Biological Association in 1953. He also received the Queen's Coronation Medal ; and in 1957 his services to seience were recognized by the award of the British Empire Medal, of which he was very proud. He retired from service in 1958 . F. S. RUSSELL

\section{NEWS and VIEWS}

New Director of the Science Museum, London : Dr. D. H. Follett

ON taking up his duties as director of the Science Museum in succession to Dr. T. C. S. Morrison-Seott (see Nature, March 26, p. 888), Dx. D. H. Follett will relinquish his post as keeper of the Department of Electrical Engineering and Communications in the Museum, to which he was appointed in 1957. Dr. Follett graduated frem Brasenose College, Oxford, in 1929, in the honours school of physies. He then entered the firm of Adam Hilger, Ltd., where he was engaged in developing the application of photoelectric methods, particularly to spectrophotometry. At the same time he carried on part-time research in cosmic rays at Birkbeck College under Prof. P. M. S. Blackett, for which he was awarded the internal degree of $\mathrm{Ph} . \mathrm{D}$. of the University of London. He joined the Science Museum staff in 1937 as assistant keeper in the Department of Physics, in which Department he remained, apart from the war years, until 1957, his special responsibility being for electricity and acoustics. During the War he served with the Meteorological Branch of the R.A.F. Volunteer Reserve and was engaged, among various duties, on the operational development of the cathode-ray direction-finding system for locating thunderstorms. He was appointed secretary of the Science Museum Advisory Council on its reconstruction in 1951 , a post which he held for six years in addition to his other museum duties. During this period he acquired a broad view of the Museum's functioning in all its aspects. Apart from his special interest in museums and the history of science-he is a Fellow of the Museums Association and a member of the British Society for the History of Science-Dr. Follett has wide interests in science generally and physics in particular. $\mathrm{He}_{\theta}$ is a Follow of the Institute of Physics, being vice-chairman of the Education Group, a Fellow of the Physical Society and a member of the Committee of Visitors of the Royal Institution.

\section{Research at the Ministry of Aviation :}

Mr. E. B. Carter

Mr. E. B. CARTER, at present serving as an assistant director in the Engine Research and Development Division of the Ministry of Aviation, has been promoted to deputy chief scientific officer and appointed director of engine production. He has a wide and varied experience of research and development on all types of aero-engine, ranging from piston engines through gas turbines to ramjets and rocket engines, which will be a considerable asset to him in his new job, in an engineering sphere where development and production are very closely linked together. Mr. Carter was born in 1912 in Halifax and received his early technical training at Halifax Technical College. On completion of the mechanical engineering course, he studied machine tool practice and was appointed assistant workshop instructor. In 1936, he became workshop superintendent and lecturer at Constantine College, Middlesbrough. Mr. Carter entered the Civil Service in 1939 on his appointment as a technical assistant in the Directorate of Engine Research and Development of the Air Ministry. From that time until 1955, his London Headquarters' service in the Air Ministry, Ministry of Aircraft Production, and Ministry of Supply alternated with periods of service as resident technical officer at the Bristol, Napier and de Havilland engine companies. In 1955, Mr. Carter was appointed assistant director in charge of research and development of ramjet and liquid-propellant rocket engines for aircraft and missiles, the post he relinquishes to take up his appointment as director of engine production.

Mr. J. D. Clare

Mr. J. D. Clare has been promoted to deputy chief scientific officer and appointed director of guided weapons research and development (Air) at the Ministry of Aviation Headquarters. In his new post he will be responsible for the development of the surface-to-air and air-to-air guided weapons for the Royal Air Force and the Army. Mr. Clare graduated at the University of Birmingham in 1940. He joined the General Electric Co., Coventry, as a student apprentice and later worked in the telecommunications laboratory on many aspects of carrier telephony systems. During this time he obtained his M.Se. In 1945 he joined Sobell Industries as head of the radio laboratory and later became assistant chief engineer responsible for both the design and development for production of commercial radio and television receivers. In 1950 he joined the Ministry of Supply 